\title{
Plant modification needs more discussion
}

Sir - Donald Ort (Nature 385, 290; 1997)

argues that " $[\mathrm{t}]$ he interspecific genetic modification of foods is not inherently new" and that "the more the focus is kept on safety of the product for humans and the environment, with decisions being made on the basis of the soundest scientific findings rather than on novelty, the better the result should be for consumers and the environment".

The idea that genetically modified organisms (GMOs) are the same as conventionally bred plants, and therefore impose no extra risks, is at odds with the intellectual property protection patenting - that is sought for GMOs. Claiming European patent protection for GMOs actually depends on proving to the European Patent Office in Munich their novelty, non-obviousness and usefulness. Genetic engineers cannot have it both ways depending on whether they are trying to allay the public's fears of GMOs or to obtain a patent.

The issue of patenting GMOs and the products and processes of genetic engineering will be discussed in the European Parliament in the next few months as the European Draft Directive on the Protection of Biotechnological Inventions (note the word 'Inventions', not 'Discoveries'). So far, there has been relatively little discussion of the many aspects involved in patenting plants, parts of humans and other animals, not least the ethical aspects.
Recent questions about the importation of genetically modified soybean into Denmark and the rest of the European Union has concentrated on whether such produce should be marked. This is essentially a discussion about the freedom of individuals to decide the food they wish to consume, irrespective of the safety issue, and is thus an issue of individual ethics. The purpose of the draft European Directive is to allow the patenting of such things as "elements isolated from the human body" (Article 3). This would almost certainly include an individual's DNA if that DNA were used to produce a drug by a company - and the company would hold the patent. Further, there is nothing in the directive to prevent even the patenting of an in vitro fertilized human embryo - only "the human body and its elements in their natural state" are excluded from patenting (Article 3). Other patentable objects would include "biological material including plants and animals" (Article 4). Exceptions to patentability seem to be made for "methods of human treatment involving germ line therapy" (that is, genetic modifications of sperm or eggs) and where "processes for modifying the genetic identity of animals cause them unnecessary suffering" (Article 4). However, exploitation of an invention cannot be prevented in the directive solely on the grounds that such an exploitation is illegal (Article 9).

When the European Parliament rejected the Draft Directive on the Protection of Biotechnological Inventions in its first round in February 1995, members of the European Parliament were widely applauded for their responsibility and sound judgement. Their decision was based on the insight that the patenting of life has implications that reach far beyond the technological and economic domain. It touches wide and deep dimensions of ethics, ecology, culture and religion. This is not to deny that inventors need rewards, but it must be remembered that a patent is a monopoly right to control the exploitation of an invention and is given to a private organization or person by society. This monopoly right must therefore respect the wider ethics and values of that society. A European Commission directive is not the way to come to a just balance between these interests. The new directive should be similarly rejected pending a full discussion of the rights, responsibilities and means of intellectual property protection within our society. The decisive arguments against the first version of the directive, raised in the parliamentary debate, are still valid and urgently need to be raised again with the present version, which still does not properly address issues of concern.

\section{John R. Porter}

Department of Agricultural Sciences,

Royal Veterinary and

Agricultural University, Agrovej 10,

2630 Taastrup, Denmark

e-mail:john.r.porter@agsci.kvl.dk

\section{Plutonium disposal}

Sir-As a recent leading article points out (Nature 384, 599; 1996), much discussion is going at present (mostly in the United States) on the policy for the disposal of excess plutonium from nuclear weapons.

An international conference,

"Utilization/disposal of excess fissile weapon materials", organized by the Landau Network under the auspices of the Italian Ministry of Foreign Affairs and Unesco in Como, Italy, in March 1996, considered the problem of the value of weapons-recovered plutonium as a reactor fuel.

Many of the invited scientists agreed that the question is essentially irrelevant for two reasons. The first is that utilities in several countries - many of them operating on strictly market rules - choose today to reprocess their fuel, partly to facilitate waste disposal and also to use the recovered plutonium in MOX fuel for their light-water reactors (LWRs), rather than disposing of it in some other way. The second is that the permanent disposition of weapon-derived plutonium as a fuel has a value that should not be measured in strictly monetary terms. The conclusions of the Como Conference are of course unofficial, but at the same time they present an independent scientific look at the problem.

On the other hand, as a follow-up of the Moscow Nuclear Safety and Security Summit in April 1996, an international meeting on "Safe and effective management of waste fissile material designated as no longer required for defence purposes" was held in Paris in October 1996. The meeting was technical and focused mainly on the management of the excess weapons plutonium. The experts concluded that there are certain options that offer prospects of early progress towards the non-proliferation and other objectives set by the Moscow Summit. These are approaches involving consumption of weapons plutonium as MOX fuel in LWRs. Immobilization is also a viable, complementary option that may be suitable for some countries in their national plutonium disposition strategy.

The experts at the Paris meeting concluded, therefore, that the MOX option, under appropriate non-proliferation conditions and international verification, offers greater promise for the management of the excess weapons plutonium. The immobilization can be an appropriate temporary component of the plutonium management strategy of some concerned nations.

We also believe that these reflections on different scientific and technological problems of nuclear security should be continued and supported by international and intellectual organizations, including Unesco, which is developing its Culture of Peace Programme with a strong scientific component.

Maurizio Martellini

Department of Physics,

University of Milano,

Italy 